\title{
ENZYME-LINKED IMMUNOSORBENT ASSAY FOR THE DETECTION OF BOTHROPS JARARACA VENOM
}

\author{
M. Barral-Netto, A. Schriefer, V. Vinhas and A. R. Almeida \\ Servico de Imunologia, Hospital Universitario Professor Edgard Santos, Universidade Federal da Bahia, \\ Salvador/Bahia/Brasil \\ (Accepted for publication 7 March 1990)
}

\begin{abstract}
M. Barral-Netto, A. Schriefer, V. Vinhas and A. R. Almeida. Enzyme-linked immunosorbent assay for the detection of Bothrops jararaca venom. Toxicon 28, 1053-1061, 1990.-This study reports an enzyme-linked immunosorbent assay for detecting Bothrops jararaca venom in fluids, employing the sandwich method with biotin/avidin amplification. The assay exhibits high accuracy in correlating optical densities with venom concentrations $(r=0.98)$, high reproducibility, low background and limited crossreactivity with venom from other snake genera. Nevertheless, it was unable to distinguish among venoms from different bothropic species. Using this method we evaluated the serum kinetics of Bothrops jararaca venom in C57BL/6 mice. High concentrations were found in serum just $15 \mathrm{~min}$ after injection $(151 \pm 41 \mathrm{ng} / \mathrm{ml}$; mean \pm S.D.), followed by a progressive fall $(102 \pm 46,74 \pm 39$ and $50 \pm 22 \mathrm{ng} / \mathrm{ml}$ after 1,3 and $6 \mathrm{hr}$ respectively), being undetectable by $24 \mathrm{hr}$. Such serum kinetics indicates a pattern of a rapid absorption of venom from the inoculation site, followed by a slow and progressive drop in its serum levels. This ELISA was a reliable tool in the determination of Bothrops jararaca venom levels in mouse serum, and may become useful in other fields of bothropic venom research.
\end{abstract}

\section{INTRODUCTION}

THE EMPLOYMENT of the ELISA in the detection of snake venoms was described by THEAKSTON et al. (1977), and since then it has been widely used for a variety of aims (COUlter et al., 1974, 1980; KHIN-OHN-LWIN and AYE-AYE-MYINT, 1982; MINTON et al., 1984). In medicine its main applications are the assessment of venom levels in serum of patients (KHIN-OHN-LWIN et al., 1984), the diagnosis of the snake genus involved in envenomation (THEAKSTON, 1984) and prevalence studies which help health care institutions to properly distribute their antivenoms (SiLAmut et al., 1987). From the research standpoint, applications range from biodistribution, kinetics in different tissues (MG-MGTHIN et al., 1985) and clearance (KHIN-OHN-LWIN et al., 1984), to evaluation of immunization protocols and antibody production in immunized animals. ELISA can also be used in the assessment of neutralization power of antiserum (SIMONSEN et al., 1987), avoiding the currently used bioassays (VIllarroel et al., 1978/1979) as recommended by the International Society On Toxinology (MEYER et al., 1986). 
Ophidism is an important public health problem in Brazil (RoDRIGUES et al., 1988). Bothrops, Crotalus and Micrurus are commonly found in this country (MINISTERIo DA SAUDE, 1986), with the bothropic genus being mainly responsible for human accidents. The establishment of the kinetics of a venom in the serum is an essential step in the development of an assay capable of calculating the dose of venom inoculated, in which at least three variables are important: (1) victim's body weight, (2) time elapsed since inoculation, and (3) serum venom levels. This knowledge would allow the development of a personalized modality of treatment, where the victim would receive only the amount of antivenom necessary to neutralize the quantity of venom injected. In this study, we developed an ELISA, applying the sandwich method with biotin/avidin amplification, for the detection of $B$. jararaca venom and report on its use in the assessment of serum venom levels in inoculated mice.

\section{MATERIALS AND METHODS}

\section{Reagents}

The venoms of Bothrops (jararaca, jararacussu, moojeni, cotiara, eritromela and atrox), Lachesis muta and Tityus serrulatus were donated by Instituto Butantan (São Paulo, SP, Brazil). The purified crotoxin was a generous gift of Dr C. Disız (Universidade Federal de Minas Gerais, Belo Horizonte, MG, Brazil). Tityustoxin purification was kindly performed by Drs I. HeNEINE and W. Beraldo (Universidade Federal de Minas Gerais, Belo Horizonte, MG, Brazil). The horse $\mathrm{F}\left(\mathrm{ab}^{\prime}\right)_{2}$ fraction anti-B. jararaca was a gift of Fundacão Ezequiel Dias (Belo Horizonte, MG. Brazil). The biotinylated anti-rabbit IgG, the avidin peroxidase complex and the peroxidase-conjugated goat anti-rabbit IgG were purchased from Sigma (St Louis, MO, U.S.A.). The rabbit anti-B. jararaca purified IgG was obtained by Protein A gel chromatography of sera collected for a rabbit immunized against $\boldsymbol{B}$. jararaca venom. All reagents were stored frozen.

\section{Rabbit immunization}

A rabbit was immunized s.c. with $250 \mathrm{ng}$ of B.jararaca venom emulsified in $0.5 \mathrm{ml}$ of complete Freund's adjuvant, followed by five other s.c. inoculations of $50 \mathrm{ng}$ of venom emulsificd in $0.5 \mathrm{ml}$ of incomplete Freund's adjuvant, in time intervals of 1-2 months. The increase in antibody levels was monitored assaying blood samples, obtained 1 week after each inoculation, with an ELISA using $B$. jararaca venom $(10 \mu \mathrm{g} / \mathrm{ml})$ for coating the plates.

Mice

Male C57BL/6 mice from our own colony, weighing between 18 and $22 \mathrm{~g}$, were maintained on a commercial balanced ration and water ad libitum. Sixteen hours prior to inoculation with venom, the animals were arranged in groups of five, receiving no water or ration.

\section{ELISA for venom detection}

Polypropylene 96-wells round-bottomed microtiter plates (Hemobag. Campinas, SP, Brazil) were coated with $0.5 \% \mathrm{~F}\left(\mathrm{ab}^{\prime}\right)_{2}$ fraction of horse anti-B. jararaca venom in carbonate-bicarbonate buffer $(\mathrm{pH} 9.6)$ for $1 \mathrm{hr}$ at $37^{\circ} \mathrm{C}$. At this and all other steps the wells were filled with $100 \mu \mathrm{l}$ volumes. The plates were washed five times with phosphate buffered saline (PBS) containing $0.05 \%$ Tween 20 and then incubated overnight at $4{ }^{\circ} \mathrm{C}$ with $3 \%$ low fat milk in carbonate-bicarbonate buffer as a blocking step. After another washing cycle a $1 \mathrm{hr}$ incubation was performed with either (1) different preparations of $B$. jararaca venom (ranging from $1 \mu \mathrm{g} / \mathrm{ml}$ to $300 \mathrm{pg} / \mathrm{ml}$ ), (2) sera of inoculated mice (diluted 1:5 in PBS), or (3) with different unrelated venom preparations (of several bothropic species and of other genera). The plates were washed again and incubated with rabbit IgG anti-B. jararaca venom for $30 \mathrm{~min}$ at $37^{\circ} \mathrm{C}$. Once again the plates were washed five times and incubated with antirabbit biotinylated antibody $1: 10,000$ in the same conditions mentioned above. Then, after another washing cycle the avidin/peroxidase complex was added to the wells in a dilution of $1: 5,000$, and the plates incubated as in the biotinylated antibody step. Measurement of the peroxidase bound to the plates was made after a last washing cycle by incubation with peroxidase substrate solution $(0.04 \%$ ortho-phenylenediamine, $0.012 \%$ hydrogen peroxide in pH 5.0 citrate-phosphate buffer) for about $15 \mathrm{~min}$ at room temperature in the dark, and the reaction was stopped by the addition of $25 \mu \mathrm{l}$ per well of $8 \mathrm{~N}$ sulphuric acid. Spectrophotometric reading using a $492 \mathrm{~nm}$ wavelength filter was then performed using a multichannel spectrophotometer (Titertek Multiskan. Flow labs, Scotland). 
For some tests we employed the standard peroxidase ELISA method (i.e. without the biotin/avidin amplification system). The difference from the above protocol was that after the incubation step with rabbit $\mathrm{IgG}$ anti-B.jararaca venom, the plates were washed and then incubated (at $37^{\circ} \mathrm{C}$ for $30 \mathrm{~min}$ ) with peroxidase conjugated goat anti-rabbit IgG (Miles Yeda), diluted 1:800. After further washing, incubation with substrate and plate reading was performed as described. Alternatively we employed a co-incubation strategy in the ELISA using the biotin/avidin protocol. B.jararaca venom and rabbit IgG anti-B.jararaca venom were added simultaneously, and the plates incubated overnight at room temperature. All further steps (from incubation with biotinylated anti-rabbit IgG on) were performed as indicated above.

\section{Serum kinetics studies}

C57BL/6 mice were divided in seven groups of five animals each. Six groups were inoculated s.c. in the right hind footpad with $10 \mu \mathrm{g}$ of $B$. jararaca venom diluted in $20 \mu \mathrm{l}$ of saline (test groups), while the last group was injected with $20 \mu \mathrm{l}$ of saline only (control group). Each group was bled at one of the following time points: 15 and $30 \mathrm{~min}$ and at $1,3,6,18$, and $24 \mathrm{hr}$ after venom inoculation (the same group was bled at $30 \mathrm{~min}$ and $24 \mathrm{hr}$ ). The control group was bled $1 \mathrm{hr}$ after saline injection. Blood samples ( 50 to $100 \mu \mathrm{l})$ were obtained by puncture of the retroorbital vessels with Pasteur pipettes. Sera were then separated from whole blood and venom levels assessed by ELISA as described above.

\section{Statistical treatment}

Using the statistical package Microstat (Ecosoft Co., version 1984), the correlations of log dose of venom and optical densities were made by the least square method and regression analysis.

\section{RESULTS}

\section{ELISA for Bothrops jararaca venom detection}

The curve "serum venom levels vs optical density" (Fig. 1) obtained from the spectrophotometric evaluation of samples with different concentrations of $B$.jararaca venom revealed high accuracy in correlating optical density (O.D.) with venom concentrations $(r=0.99)$. The comparison of the curves on each and on different plates, revealed a small inter-test and intratest optical reading variation (Table 1).

\section{Cross-reactivity among different snake venoms}

In an attempt to investigate the degree of cross-reactivity among different venoms and $B$. jararaca venom using this test, known preparations of several bothropic species as well as of two other genera were assayed and the curves "venom concentration vs optical

TABle 1. INTRA- AND INTER-ASSAY VARIABILITY AMONG OPTICAL DENSITIES IN THE DETERMINATION OF $B$. jataraca VENOM BY ELISA, PERFORMED IN DUPLICATES IN FOUR TESTS

\begin{tabular}{|c|c|c|c|c|c|c|c|c|}
\hline \multirow{2}{*}{$\begin{array}{c}\text { Venom } \\
\text { concentration } \\
(\mathrm{ng} / \mathrm{ml})\end{array}$} & \multicolumn{8}{|c|}{ Assays* } \\
\hline & \multicolumn{2}{|c|}{ Test 1} & \multicolumn{2}{|c|}{ Test 2} & \multicolumn{2}{|c|}{ Test 3} & \multicolumn{2}{|c|}{ Test 4} \\
\hline 1000 & 849 & 819 & 952 & 1033 & 934 & 824 & 1472 & 1522 \\
\hline 300 & 722 & 622 & 842 & 928 & 920 & 805 & 1432 & 1500 \\
\hline 100 & 608 & 618 & 739 & 667 & 759 & 730 & 1108 & 1302 \\
\hline 30 & 492 & 466 & 548 & 536 & 600 & 503 & 920 & 937 \\
\hline 10 & 262 & 273 & 371 & 364 & 372 & 315 & 474 & 477 \\
\hline 3 & 127 & 143 & 226 & 235 & 177 & 144 & 214 & 243 \\
\hline 1 & 50 & 65 & 132 & 137 & 96 & 71 & 75 & 63 \\
\hline 0.3 & 9 & 32 & 80 & 77 & 49 & 32 & 28 & 38 \\
\hline
\end{tabular}

*All values represent absorbance readings multiplied by 1000 . 


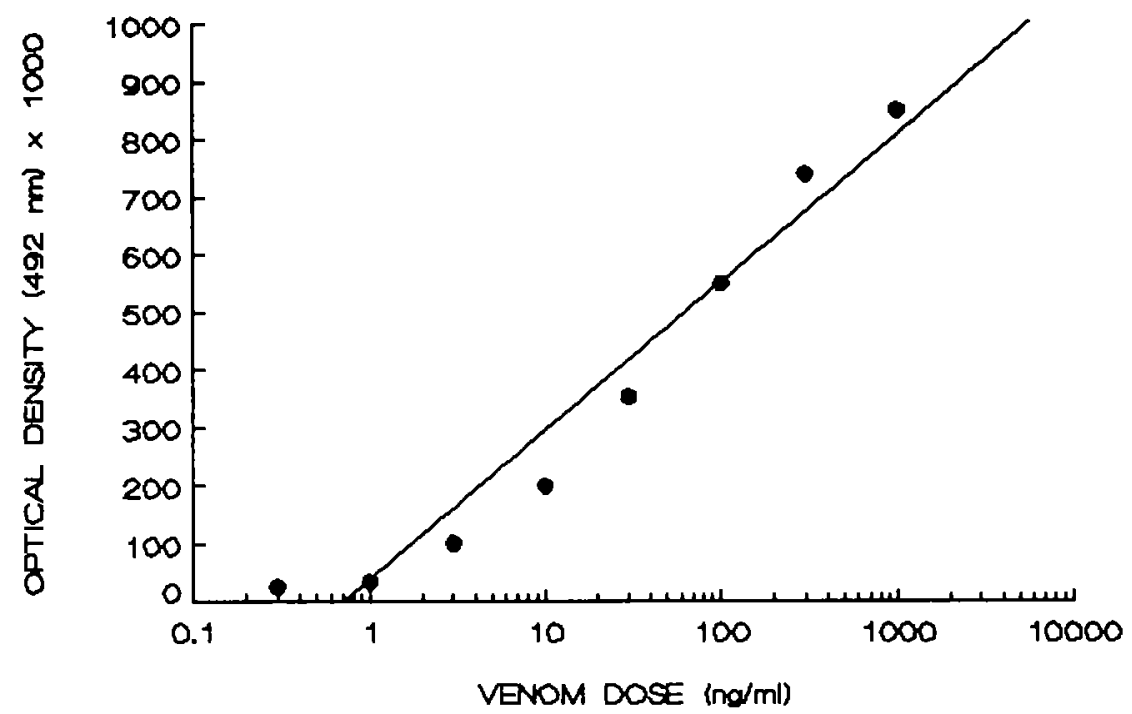

Fig. 1. SOLUTIONS OF Bothrops jararaca VENOM, RANGING FROM $0.3 \mathrm{ng} / \mathrm{ml}$ to $1 \mu \mathrm{g} / \mathrm{ml}$, WERE ASSAYED BY ELISA WITH BIOTIN/AVIDIN AMPLIFICATION.

The resulting optical densities were correlated to the venom concentrations and the linear regression performed by the least squares method $(r=0.98)$. A representative experiment is shown.

density" were plotted (Fig. 2). There was extensive cross-reactivity among venoms of different bothropic species, with the exception of $B$. jararacussu. There was no significant cross-reactivity with venoms of other genera tested, such as Lachesis and Crotalus (Fig. 2). Limited detection occurred only when they were in extremely high concentrations (in the order of $1 \mu \mathrm{g} / \mathrm{ml}$ ). Purified tityustoxin (from the scorpion Tityus serrulatus) was also tested using this assay and showed no cross-reactivity; optical density values were similar to those reflecting background.

\section{Comparison among different ELISA procedures}

Searching for optimization of the test, including time spent and sensitivity, we compared the standardized ELISA with two variants using the same peroxidase system. When employing the standard peroxidase test the background was much higher than with the biotin/avidin system, the test being unable to discriminate among high venom concentrations (above $1 \mu \mathrm{g} / \mathrm{ml}$ ). Furthermore the correlation between optical density and venom concentration did not follow the smoothly ascending pattern of that obtained with the biotin/avidin system (Table 2). In the comparison between both biotin/avidin assays ("sequential incubation" and "co-incubation") the plates were incubated with venom preparations ranging from $100 \mathrm{pg} / \mathrm{ml}$ to $1 \mathrm{mg} / \mathrm{ml}$ and the curves obtained by spectrophotometric reading of the optical densities of those samples were plotted in Fig. 3 . The curve obtained from sequential incubation presents a plateau when venom concentrations are higher then $1 \mu \mathrm{g} / \mathrm{ml}$, then it starts to drop as the venom concentration decreases. The coincubation curve, on the other hand, shows a more complex pattern, ascending as concentration of venom decreases, reaching a peak between concentrations of $10 \mathrm{ng} / \mathrm{ml}$ and $1 \mathrm{ng} / \mathrm{ml}$, and then dropping in a pattern similar to that seen in the sequential 


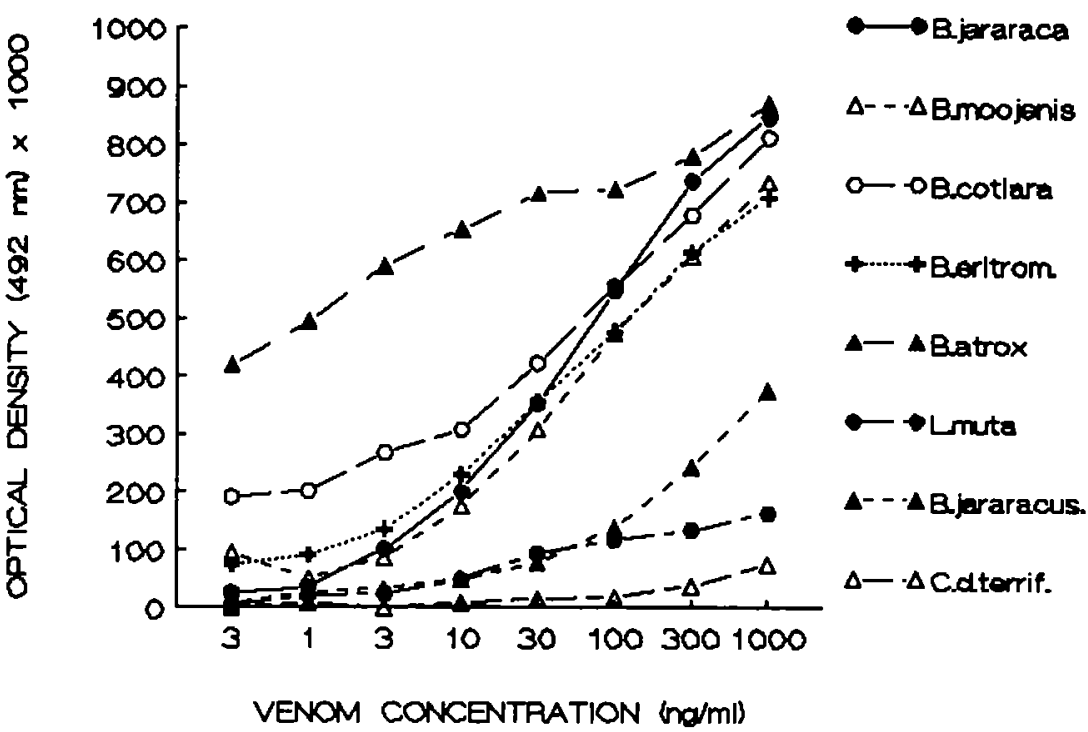

Fig. 2. DifFerent VENOM PREPARATIONS OF VARIOUS Bothropic SPECIES, Lachesis AND OF Crolalus durissus terrificus WERE ASSAYED BY ELISA FOR Bothrops jararaca VENOM DETECTION.

The resulting optical densities were plotted against their concentrations. (B. eritrom = B. eritromelas; $B$. jararacus. $=$ B. jararacussu; $C$.d. terrif. $=$ Crotalus durissus terrificus).

incubation assay. From the figure we can further state that the co-incubation test shows a sensitivity higher than that of the sequential incubation test, since at low venom concentrations (below $10 \mathrm{ng} / \mathrm{ml}$ ) it gave absorbance values higher than those obtained by the sequential incubation method.

Serum kinetics of Bothrops jararaca venom

We used the sequential incubation biotin/avidin assay in the evaluation of the serum kinetics of bothropic venom (B.jararaca) in mice. The results of the spectrophotometric

TABlE 2. COMPARISON OF abSORBANCES OF KNOWN VENOM CONCENTRATIONS ASSAYED BY ELISAS EMPLOYING EITHER BIOTIN/ AVIDIN OR STANDARD PEROXIDASE SYSTEM

\begin{tabular}{crcrc}
\hline $\begin{array}{c}\text { Venom } \\
\text { concentration } \\
(\mathrm{ng} / \mathrm{ml})\end{array}$ & \multicolumn{4}{c}{ Absorbance (492 nm)* } \\
\cline { 2 - 5 } & Standard peroxidase & Biotin/avidin \\
\hline 1000 & $\dagger$ & $\dagger$ & 849 & 816 \\
300 & 1910 & $\dagger$ & 739 & 698 \\
100 & 1677 & 1840 & 548 & 559 \\
30 & 1211 & 1360 & 353 & 388 \\
10 & 621 & 766 & 200 & 214 \\
3 & 242 & 347 & 101 & 93 \\
1 & 72 & 119 & 35 & 47 \\
0.3 & 29 & 59 & 26 & 25 \\
\hline
\end{tabular}

*Values represent absorbance readings multiplied by 1000 .

†Absorbances above measurable range. 


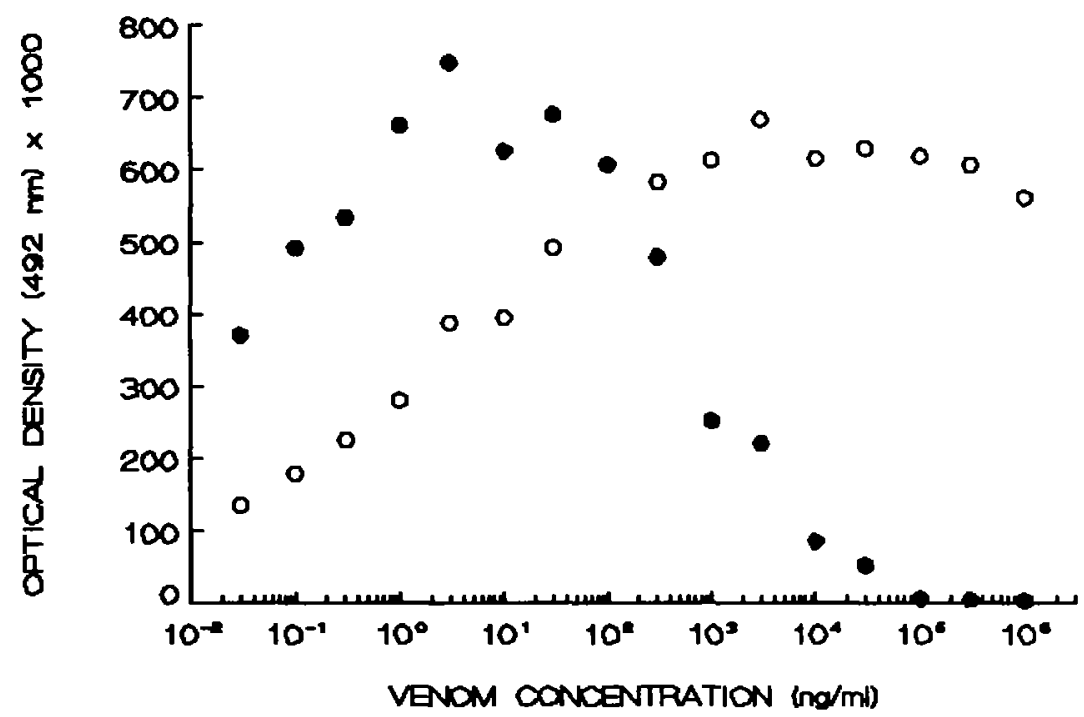

FIG. 3. DIFFERENT KNOWN PREPARATIONS OF Bothrops jararaca VENOM WERE ASSAYED BY ELISA APPLYING EITHER SEQUENTIAL INCUBATION OF VENOM AND ITS ANTI-VENOM (O) OR CO-INCUBATION OF BOTH (O).

The resulting optical densities were plotted against venom concentrations.

assays of the sera samples are shown in Fig. 4. There was a rapid absorption of the venom from the site of inoculation to the blood, with venom blood concentration high just 15 min after inoculation. After this high concentration, the serum levels of venom dropped slowly and progressively, and venom was not detectable $24 \mathrm{hr}$ after injection. Based on

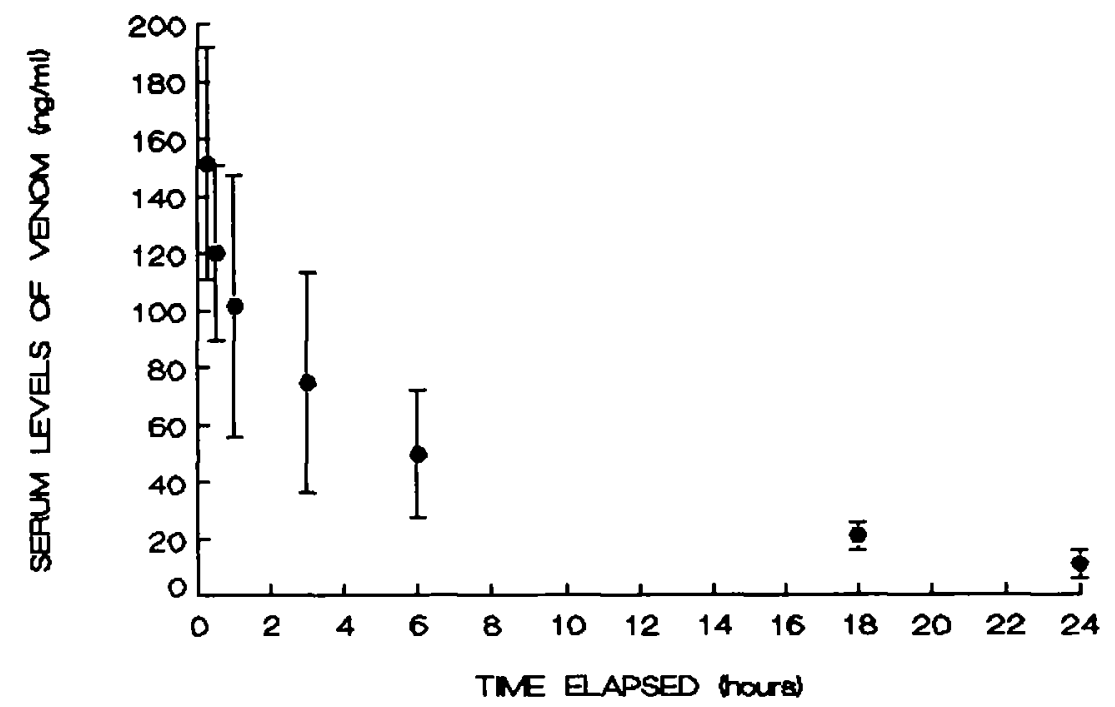

FIG. 4. SEVEN GROUPS OF FIVE C57BL/6 MICE WERE INJECTED WITH $10 \mu \mathrm{g}$ of Bothrops jararacia VENOM IN THF HIND FOOTPAD AND BLED 15 AND 30 MIN AND 1, 3, 6, 18 AND 24 HR AFTER INOCULATION.

The serum samples were assayed by ELISA for Bothrops jararaca venom detection. Points represent means of groups' values, and error bars represent standard deviations. 
values obtained from serum samples of the control group of mice $(11.8 \pm 1.4 \mathrm{ng} / \mathrm{ml})$, the lowest amount of venom reliably detected by the test was $14.6 \mathrm{ng} / \mathrm{ml}$, which corresponds to the mean plus two standard deviations of the hypothetical venom levels encountered in the blood samples of this group (by interpolating absorbance values in the standard curve made with known venom concentrations).

\section{DISCUSSION}

The ELISA reported herein for detection of bothropic venom is characterized by low background, high reproducibility and high efficiency in calculating serum levels of venom from optical densities. Thus, this test is a very reliable means of evaluating bothropic venom concentrations, allowing its use in the study of the serum kinetics of this venom. Its use for clinical purposes, however, is not established. Bothrops venom is a mosaic of different proteins, many of which may not be important toxic components. A reliable ELISA test for clinical use must specifically evaluate the serum levels of relevant toxic fractions.

The presence of high background readings is a major problem in enzyme immunoassays, and some solutions have been discussed elsewhere (Ho et al., 1986). In our tests, the use of low fat milk resulted in very low background when compared to the same assay without overnight incubation with milk (data not shown). Those background levels were even lower when the reagents were diluted with $3 \%$ low fat milk in phosphate buffered saline (PBS) instead of PBS alone in the other steps of the test (data not shown).

The test showed high specificity for detecting bothropic venom as assessed by the low cross-reactivity with venoms of other snake genera and of the scorpion $T$. serrulatus, but failed to distinguish the $B$. jararaca venom from several other bothropic venoms. The only bothropic venom tested that displayed low cross-reactivity with $B$.jararaca venom was that of the B.jararacussu species, which is in accordance with the lower antigenic similarity of this venom with that of $B$.jararaca already discussed by VILLARRoEL et al. $(1974 a, b, 1976 / 1977)$. The venom of $B$. atrox gave higher O.D. values than those obtained from the venom of $B$. jararaca used for immunization. It is possible that $B$.atrox venom contains a high proportion of the immunogenic proteins and this point deserves further examination. The sensitivity was also high, detecting venom in concentrations of 1-3 $\mathrm{ng} / \mathrm{ml}$, which are lower than the average circulating levels of venom, reported for other snake venoms (KHIN-OHN-LWIN et al., 1984; Silamut et al., 1987), in bitten patients.

The strange pattern observed in the co-incubation test was probably due to removal of the rabbit anti-Bothrops IgG by an excess of antigen. At high concentrations (greater than $10 \mathrm{ng} / \mathrm{ml}$ ) there was an inverse relation between venom levels and O.D. In venom concentrations lower than $1 \mathrm{ng} / \mathrm{ml}$, the pattern was similar to that disclosed by the sequential incubation assays. On the other hand, the co-incubation test displayed a sensitivity greater than that of the sequential incubation assay at low venom concentrations, as shown by the higher absorbances at similar venom concentrations (Fig. 3 ). The possibility of having similar O.D.s with two largely different venom concentrations, precludes the use of the co-incubation test in the evaluation of serum venom levels. Such procedure may have a place within research laboratories for the detection of very low venom concentrations, outside the range of reliability of the sequential incubation assay.

The described ELISA has many potential uses besides assessing the kinetics of bothropic venom. For instance it might be employed in epidemiological studies. From the purely 
clinical standpoint, however, its use is precluded by the long time it takes and the lack of specificity in determining the actual levels of toxic components of the venom. With precoated plates, it takes about $5 \mathrm{hr}$ which is unusable since a $3 \mathrm{hr}$ delay in treatment significantly increases morbidity. Nevertheless, it may be possible to develop an optimized version that would match the time requirements for clinical use (DHALIwal et al., 1983) and the need for specificity in the detection of the toxic components of the venom.

The kinetics of $\boldsymbol{B}$. jararaca venom in mice sera disclosed early elevated venom concentrations followed by a progressive drop in serum levels. The inoculations were done s.c. in the hind footpad in an attempt to resemble the most frequently found conditions in human accidents (i.e. s.c. or i.m. bites in the lower limbs). There was a fast absorption of venom from the site of inoculation, with high serum venom levels just $15 \mathrm{~min}$ after injection. If the same happens in humans, it correlates well with the increased morbidity associated with the delay of treatment. However, the slow clearance of the venom from the serum after the early peak is indicative of a slow rate of diffusion to other tissues. This might explain the overall low mortality involved in accidents with this snake genus (RODRIGUES et al., 1988). The patients normally receive anti-ophidic therapy several hours after accidents, causing an increased frequency of local sequelae, but because of the slow penetration into vital organs, the treatment may still be capable of preventing the patient's death.

Lastly, the determination of the kinetics is also important if one is attempting to develop a personalized modality of treatment, in which the amount of antivenom to be given to the patient is determined on the basis of the quantity of venom inoculated. In such an approach we envision an equation correlating the variables (including victim's body weight, serum venom level and time elapsed since inoculation) to the amount of inoculated venom. A better knowledge of venom serum kinetics in different animal species, especially those more similar to man, may help define an approach.

Acknowledgements-The authors thank Mr VANILSON SOUZA and Marcondes Silva for their excellent animal care and technical support. A. SCHRIEFER is a recipient of a CNPq's (Conselho Nacional de Desenvolvimento Cientifico e Tecnologico) scientific initiation fellowship. This project was supported by Financiadora de Estudos e Projetos (FINEP).

\section{REFERENCES}

Coulter, A. R., Sutherland, S. K. and Broad, J. (1974) Assay for snake venom in tissue fluids. J. Immunol. Methods 4, 297-300.

Coulter, A. R., Harris, R. D. and Sutherland, S. K. (1980) Enzyme immunoassay for the rapid clinical identification of snake venom. Med. J. Aust. i, 433-438.

Dhaliwal, J. S., Lim, T. M. and Suxumaran, K. A. (1983) A double antibody sandwich micro-ELISA kit for the rapid diagnosis of snake bite. South East Asian J. Trop. Med. Public Health 14, 367-373.

Ho, M., Warrell, M. J., Warrell, D. A., BidWell, D. and Voller, A. (1986) A critical reappraisal of the use of enzyme linked immunosorbent assays in the study of snake bite. Toxicon 24, 211-221.

KHIN-OHN-LWIN and AYE-AYE-MYINT (1982) The use of enzyme linked immunosorbent assay (ELISA) in the detection of Russell's viper venom in body fluid. Snake 14, 77-82.

KhIn-OHn-Lwin, AYe-Aye-Myint, Tun, P., Nive, T. and Naing, M. (1984) Russell's viper venom levels in serum of snake bite victims in Burma. Trans. Roy. Soc. Trop. Med. Hyg. 78, 165-168.

Meier, J., Banks, B., Creppy, E. E., Habermehl, G., Kornalik, F., LeE, C.-Y., Mebs, D., Rosenberg, P. and THEAKSTON, R. D. G. (1986) Ethical standards and guidelines for animal experiments in toxinological research. Toxicon 24, 327-330.

Mg-Mg-Thin, Thein-TaN and Hla-PE (1985) Relationship of administered dose to blood venom levels in mice following experimental envenomation by Russell's viper (Vipera russeli) venom. Toxicon 23, 43-49.

Ministerio DA SAUDE Do Brasil (1986) Report of the "II reunião tecnica sobre ofidismo: distribuicão geografica das serpentes do Brasil". (Brasilia). 
Minton, S. A., Weinstein, S. A. and Wilde, C. E. (1984) An enzyme-linked immunoassay for detection of North American pit viper venoms. Clin. Toxicol. 22, 303-316.

Rodrigues, D. S., Teles, A. M. S., Machado, M. A. M. L., Vargens, M. M. L., Nascimento, I. M. and Planzo, T. M. P. (1988) Ofidismo na Bahia: um problema de saude publica. Rev. Soc. Bras. Toxicol. 1, $23-26$.

Silamut, K., Ho, M., Looareesuwan, S., Viravan, C., Wuthiekanun, V. and Warrell, D. (1987) Detection of venom by enzyme-linked immunosorbent assay (ELISA) in patients bitten by snakes in Thailand. Br. Med.J. 294, 402-404.

Simonsen, O., Schon, C. and Heron, 1. (1987) Modification of the ELISA for the estimation of tetanus antitoxin in human sera. J. Biol. Stand. 15, 143-157.

Theakston, R. D. G. (1984) The use of enzyme immunoassay in snake venom research. Proc. 6th Eur. Symp. Animal, Plant and Microbial Toxins (Basle), 9-20.

Theakston, R. D. G., Lloyd-Jones, M. J. and ReID, H. A. (1977) Micro-ELISA for detecting and assaying snake venoms and venom-antibody. Lancet 2, 639-641.

Villarroel, M. S., Zelante, F., Furlanetto, R. S. and Rosa, R. R. (1974a) Contribuicão ao estudo imunoquimico de venenos botropicos I: analise comparativa dos componentes antigenicos de seis especies de venenos frente a seus respectivos antivenenos, atraves das tecnicas de dupla difusão e imunoeletroforese em gel de agar. Mem. Inst. Butantan 38, 13-30.

Villarroel, M. S., Furlanetto, R. S., Rosa, R. R., Zelante, F. and Navas, J. (1974b) Contribuicão ao estudo imunoquimico de venenos botropicos II: analise comparativa dos componentes antigenicos comuns de seis especies de venenos botropicos. Mem. Inst. Butantan 38, 31-40.

Villarroel, M. S., Furlanetto, R. S., Zelante, F. and Rosa, R. R. (1976/1977) Contribuicão ao estudo imunoquimico de venenos botropicos III: analise dos componentes antigenicos comuns atraves da dupla difusão em gel de agar. Mem. Inst. Butantan 40/41, 241-250.

Villarroel, M. S., Rosa, R. R., Zelante, F. and Furlanetto, R. S. (1978/1979) Padronizacão da avaliacão da potencia de antivenenos botropicos, em camundongos. Mem. Inst. Butantan 42/43, 325-336. 